Article

\title{
Susceptibility of Dalotia coriaria (Kraatz) \\ (Coleoptera: Staphylinidae) to Entomopathogenic Nematodes (Rhabditida: Heterorhabditidae and Steinernematidae)
}

\author{
Joseph Tourtois and Matthew J. Grieshop* \\ Department of Entomology, Michigan State University, East Lansing, MI 48824, USA; \\ E-Mail: riddlej2@msu.edu
}

* Author to whom correspondence should be addressed; E-Mail: mgrieshop@msu.edu;

Tel.: +1-517-432-8034.

Academic Editor: Andrew G. S. Cuthbertson

Received: 26 January 2015 / Accepted: 6 March 2015 / Published: 18 March 2015

\begin{abstract}
Dalotia coriaria (Kraatz) (Coleoptera: Staphylinidae) and entomopathogenic nematodes (Rhabditida: Heterorhabditidae and Steinernematidae) are two soil-dwelling biological control agents used to manage western flower thrips, Frankliniella occidentalis (Pergande) (Thysanoptera: Thripidae) and fungus gnats Bradysis spp. (Diptera: Sciaridae) in glasshouses. Growers often use multiple natural enemies to achieve economic control, but knowledge of interactions among natural enemies is lacking. We conducted a laboratory bioassay to test the pathogenicity of four commercially available nematode species-Heterorhabditis bacteriophora Poinar (Rhabditida: Heterorhbditidae), Steinernema carpocapsae (Weiser) (Rhabditida: Steinernematidae), S. feltiae (Filipjev), and $S$. riobrave Cabanillas et al.- to third instar and adult $D$. coriaria. Third instars were three times more susceptible than the adults to the entomopathogenic nematodes. Mortality for $D$. coriaria adults and third instars treated with $S$. feltiae and H. bacteriophora was lower than the mortality for $D$. coriaria adults and third instars treated with $S$. carpocapsae and $S$. riobrave. Neither infective juvenile foraging behavior nor size correlates with $D$. coriaria mortality. Dalotia coriaria appears to be most likely compatible with applications of S. feltiae and H. bacteriophora.
\end{abstract}

Keywords: Dalotia (= Atheta) coriaria; entomopathogenic nematodes; intraguild predation 


\section{Introduction}

Dalotia coriaria (Kraatz) (Coleoptera: Staphylinidae) and entomopathogenic nematodes are two soil-dwelling biological control agents used to manage common greenhouse pests including: thrips, fungus gnats, and shore flies. The use of biological control in greenhouses has become more desirable due to the development of pesticide resistance in pest populations [1]. Growers often use multiple natural enemies to achieve economic control but knowledge of interactions among natural enemies is lacking.

Western flower thrips, Frankliniella occidentalis (Pergande) (Thysanoptera: Thripidae) is a major pest of vegetable production and floriculture in greenhouses and nurseries [2,3]. Due to their cryptic behaviors (eggs laid in plant tissue, pupation occurs in the soil, and feeding on developing tissues) and their resistance to many insecticides, biological control has become increasingly important to successful western flower thrips management programs [2-5]. Both entomopathogenic nematodes and D. coriaria are employed to target the soil-dwelling stage of western flower thrips (i.e., prepupae and pupae).

Fungus gnats Bradysis spp. (Diptera: Sciaridae) are also major pests in greenhouses. Fungus gnat larvae feed on many plant roots. Nematodes and D. coriaria are recommended soil-dwelling biological control agents to target this pest. Five species of Heterorhabditis and four species of Steinernema have been tested for controlling fungus gnats [6-8]. Steinernema feltiae is often the leading performer in controlling fungus gnats. Both larval and adult D. coriaria feed on fungus gnat eggs and larvae [9].

Dalotia coriaria is a small (3-4 mm), highly mobile, soil-dwelling polyphagous predator. Larvae are a pale yellow to cream color; and the adults are a glossy, dark color [10]. The body posture of the adults is typically S-shaped with their heads pointed down and their abdomens upturned. Both the larvae and adults are polyphagous - feeding on multiple life stages of mites and other insects [9-11].

Adult $D$. coriaria are voracious predators and have been shown to consume as many as 95 second instar thrips, 78 thrips pupae, 154 fungus gnat eggs, or 150 first instar fungus gnats within $24 \mathrm{~h}$ [9]. Third instar beetles can consume an equally impressive 100 eggs and 100 first instar fungus gnats in a $24 \mathrm{~h}$ period [9]. In a laboratory bioassay, one adult rove beetle can consume $68 \%-78 \%$ of the second and third instar fungus gnats presented to them in Petri dishes within $24 \mathrm{~h} \mathrm{[12].}$

In a screened greenhouse trial with Impatiens (L.) (Ericales: Balsaminaceae), D. coriaria reduced western flower thrips populations by 53\%-82\% [13]. On caged Gerbera jamesonii (Bolus ex Hook) (Asterales: Asteraceae) and Chrysanthemums spp. (Asterales: Asteraceae), D. coriaria did not reduce western flower thrips populations with thrips ranging from 1-1.8 to 6.9-7 on G. jamesonii and Chrysanthemums spp., respectively [5]. In a field experiment with five or 10 adult rove beetles per caged parsley Petroselinum crispum (Mill.) Nyman ex A. W. Hill (Apiales: Apiaceae) pot, there were 75\% and $85 \%$ fewer fungus gnat adults on yellow sticky cards compared to the control over a $22 \mathrm{~d}$ period [13]. In a follow-up experiment, two adult rove beetles reduced the number of fungus gnats on yellow sticky cards by $48 \%$ [14].

Entomopathogenic nematodes in the families Heterorhabditidae and Steinernematidae are soil dwelling round worms that are obligate parasites of insects. Infective juveniles (IJ) (or dauer larvae) enter insect hosts through natural openings - mouth, anus, and spiracles. Inside the insect haemocoel, the juvenile nematodes release their symbiotic bacteria and kill the host within $24-48 \mathrm{~h}$. Nematodes complete their development within the host, proceeding through one to three generations. When host resources are depleted, thousands of infective juveniles emerge from the cadaver in search of a new host [15]. 
Heterorhabditis bacteriophora Poinar (Rhabditida: Heterorhbditidae), Steinernema carpocapsae (Weiser) (Rhabditida: Steinernematidae), S. feltiae (Filipjev), and S. riobrave Cabanillas et al. are four commonly available entomopathogenic nematodes.

Heterorhabditis bacteriophora, S. feltiae, and $S$. carpocapsae can infect $>50 \%$ of second instar thrips and prepupae and $11 \%-54.5 \%$ of the pupae [16]. Heterorhabditis (12 strains) and 16 strains of Steinernema have been screened for infectivity in western flower thrips in several laboratory studies [16-19]. Thrips mortality ranged from 0 to $75 \%$. Chyzik et al. (1996) found that H. bacteriophora HP88 was the most effective at reducing western flower thrips populations by 39\%. Ebssa et al. (2001) reported $>50 \%$ thrips prepupae mortality for several nematode strains. They chose H. bacteriophora HK3, S. feltiae Sylt, and $S$. carpocapsae DD136 as the strain that caused the highest mortality for each species. Premachandra et al. (2003) chose H. bacteriophora HK3 and S. feltiae Nemaplus ${ }^{\circledR}$ as the most effective nematodes. Ebssa et al. (2004) identified H. indica Poinar, Karunakar and David and S. bicornutum Tallosi, Peters and Ehlers as the nematode species from each genus for causing the highest western flower thrips mortality. Thus, multiple nematode species and strains in both genera can be used for thrips management.

Entomopathogenic nematode host searching strategy is generally considered to be on a continuum from cruiser to ambusher [15,20]. Cruisers such as H. bacteriophora move through the soil in search of a host [21]. Ambushers like S. carpocapsae, perform a behavior known as nictitating, where they elevate $95 \%$ of their body and wave back and forth, waiting for a host to pass by [22]. Nematodes such as $S$. feltiae and $S$. riobrave are intermediate in their search strategy and display both behaviors [23]. Ambushers are often applied to target mobile hosts and cruisers are often applied to target stationary hosts. Thus, it is possible that $D$. coriaria, which is highly mobile, may more likely be infected by an ambusher, $S$. carpocapsae, than the cruiser, H. bacteriophora.

Dalotia coriaria and entomopathogenic nematodes are both soil-dwelling organisms used as biological control agents to manage the same pests, i.e. western flower thrips, fungus gnats, and shore flies; therefore, both could be applied at the same time and come into contact with each other. To date a single study has tested the compatibility of $D$. coriaria with one species of nematode, S. feltiae, and concluded that the two organisms are likely compatible for simultaneous release [11]. Biological control companies recommend the use of $S$. feltiae to control both thrips and fungus gnats; however, other nematode species have also been shown to be effective against western flower thrips. A handful of laboratory studies screened multiple nematode species against western flower thrips and found that nematode species such as $H$. bacteriophora, $H$. indica, and $S$. bicornutum killed similar numbers or more thrips prepupae than S. feltiae [16-19]. Jandricic et al. (2006) showed that S. feltiae is capable of infecting third instar D. coriaria in a laboratory bioassay, but only $16 \%$ of the mortality confirmed nematode infection at the highest dose — 50 infective juveniles (IJ)/ $\mathrm{cm}^{2}$. In a microcosm bioassay, $100 \mathrm{IJ} / \mathrm{cm}^{2}$ caused $25 \%$ mortality of third instars [11]. The objective of this study was to determine the susceptibility of $D$. coriaria third instars and adults to four commonly used species of entomopathogenic nematodes: $H$. bacteriophora, S. carpocapsae, S. feltiae, and $S$. riobrave.

\section{Experimental Section}

We conducted a $4 \times 3 \times 2$ factorial experiment to test the pathogenicity of four nematode species-H. bacteriophora, S. carpocapsae, S. feltiae, and S. riobrave-at multiple doses-one-half, 
one, and two times the recommended rate of application [24] — for two life stages of D. coriaria — third instar and adult. There were 24 treatments plus two controls - adult and third instar beetles without nematodes.

\subsection{Insect Rearing and Nematode Cultures}

We established laboratory colonies of $D$. coriaria with beetles purchased from BioBest (Leamington, ON, Canada) and Syngenta (Little Clacton, UK). Beetles used for this study were either laboratory reared or purchased from IPM Laboratories Inc. (Locke, New York, NY, USA). Laboratory colonies were reared in two different sized plastic containers. One plastic container was a $2.25 \mathrm{~L}$ rectangle box from Ziploc (Racine, WI, USA). We drilled two ventilation holes (dia $2.54 \mathrm{~cm}$ ) into the lid and covered the holes with bridal veil. Since four of these containers did not supply enough beetles for the experiment, we increased $D$. coriaria rearing production with four additional larger (9.4 L capacity) rectangular plastic containers from Rubbermaid (High Point, NC, USA). We drilled two ventilation holes (dia $7.62 \mathrm{~cm}$ ) into the lid and covered the holes with bridal veil. Both containers contained grounded coconut husk (coir) (Canna Continental, Los Angeles, CA, USA) and vermiculite (Good Earth Horticulture, Inc. Lancaster, NY, USA) (50:50 ratio) as a substrate. The smaller container held $1 \mathrm{~L}$ of substrate, and the larger container held $6 \mathrm{~L}$ of substrate. We kept containers on a laboratory bench under ambient conditions $\left(22.0 \pm 0.9^{\circ} \mathrm{C}, 47.9 \% \pm 18.4 \% \mathrm{RH}\right)$ near windows and subjected to the natural light cycle. We feed the beetles certified organic chicken feed (HiLo Acres, Portland, MI, USA) on a weekly schedule $-15 \mathrm{~mL}$ to the smaller and $30 \mathrm{~mL}$ to the larger containers. Chicken feed was mixed into the media and water was added as needed to maintain moisture $[13,14]$.

Heterorhabditis bacteriophora Oswego strain was obtained from a laboratory culture (Anne Nielsen, Rutgers Agriculture Research and Extension Center, Bridgeton, NJ, USA). Steinernema carpocapsae and $S$. feltiae were obtained from BeckerUnderwood (Ames, IA, USA). Steinernema riobrave 355 strain was obtained from David Shapiro-Illan, USDA-ARS, Byron, GA, USA. The four nematode species were reared on late instar Galleria mellonella (L.) (Lepidoptera: Pyralidae) in laboratory colonies. Five G. mellonella were placed on filter paper in an inverted Petri dish and infected with 500 infective juveniles (IJ) in aqueous solution [25]. Infective juveniles were harvested using a White trap [26] and stored in $600 \mathrm{~mL}$ tissue culture flasks with vented cap (Corning Inc., Tewksbury, MA, USA) in the dark, under ambient laboratory conditions. We deposited beetle and nematode voucher specimens in the Michigan State University A.J. Cook Arthropod Research Collection (voucher number 2014-08).

\subsection{Experimental Methods}

The test arena consisted of a $1.7 \mathrm{~mL}$ microcentrifuge tube (Denville Scientific Inc., South Plainfield, NJ, USA) with a hole (approx. $0.045 \mathrm{~mm}$ ) in the lid to allow air exchange [27]. We cut a piece of No. 1 Whatman filter paper (dia $55 \mathrm{~mm}$ ) into eight equal radial slices. We inserted a slice into each tube to provide a substrate for nematodes and to help regulate relative humidity. We added one grain of organic rolled oats to each tube as supplemental food for the beetles. Infective juveniles were applied in aqueous solution $(50 \mu \mathrm{L})$ to the filter paper and one beetle was added per tube [27].

The recommended rate of nematode application is $100 \mathrm{IJ} / \mathrm{cm}^{2}$ for western flower thrips management [24] and the cap of the microcentrifuge tubes used in the experiment were approximately $1 \mathrm{~cm}^{2}$. Thus, one-half, one, and two times the recommended rate was calculated at $50 \mathrm{IJ} / \mathrm{cm}^{2}, 100 \mathrm{IJ} / \mathrm{cm}^{2}, 200 \mathrm{IJ} / \mathrm{cm}^{2}$. Infective juveniles were used within $14 \mathrm{~d}$ of harvest from laboratory colonies. 
Availability of sufficient beetles determined experimental timing. From June to August 2014, two to four replicates were set-up and run at a time, until 20 replicates were completed. In each replicate, there was one tube for each treatment and four tubes each for adult and third instar controls. We assessed nematode viability for each run by infecting $G$. mellonella. For each nematode species, we placed eight G. mellonella in an inverted $9 \mathrm{~cm}$ Petri dish with 160 infective juveniles. Arenas and Petri dishes were placed in a growth chamber set at $24.4 \pm 0.3{ }^{\circ} \mathrm{C}, 92.7 \% \pm 15.2 \% \mathrm{RH}$, with $24 \mathrm{~h}$ darkness. Beetle mortality was assessed daily for $4 \mathrm{~d}$. The experiment was terminated on the fourth day due to excessive fungal growth in the arenas. All the tubes were placed in the freezer $\left(-20^{\circ} \mathrm{C}\right)$. We dissected the dead beetles to check for the presence of nematodes.

\subsection{Statistical Analysis}

We excluded the last four replicates of beetles exposed to $H$. bacteriophora from the analysis because the G. mellonella were poorly infected (i.e., $<88 \%$ infection). We excluded three tubes each of adult and larval beetles in the control from one replicate from the analysis since holes were not punctured into the lid of the microcentrifuge tubes. Lastly, we excluded one entire block from analysis since nematodes were found in the dead beetles in the control treatments.

Since each treatment has represented only once in each block (replicate), we could not calculate a corrected mortality for each replicate. Our data was binary and collected for multiple days, thus we utilized survival analysis. Survival analysis was tested with Cox's proportional hazard function using PROC PHREG in SAS 9.3 [28,29]. Beetle mortality was modeled by insect stage, nematode species, dose rate, and interaction terms. Terms with a $p$-value $>0.15$ were dropped from the model. A logistic regression was performed using the $\mathrm{R}$ statistical language [30] to compare the number of infected beetles per treatment. Beetle infection was modeled by insect stage, nematode species, dose rate, and interaction terms. The step function was used to select a reduced model based on the lowest AIC value (Table 1). Multiple comparisons of the slopes were conducted using the contrast package [31].

Table 1. Model selection based on AIC values using the step function in R 3.1.1.

\begin{tabular}{cc}
\hline Model & AIC \\
\hline EPN + Rate + stage + EPN:Rate + EPN:stage + Rate:stage + EPN:Rate:stage + Block & 263.33 \\
EPN + Rate + stage + EPN:Rate + EPN:stage + Rate:stage + EPN:Rate:stage & 255.15 \\
EPN + Rate + stage + EPN:Rate + EPN:stage + Rate:stage & 252.82 \\
EPN + Rate + stage + EPN:Rate + EPN:stage & 250.80 \\
EPN + Rate + stage + EPN:Rate & 249.30 \\
\hline
\end{tabular}

$\mathrm{EPN}=$ entomopathogenic nematode, Rate $=$ dose of infective juveniles, stage $=$ developmental stage of $D$. coriaria.

\section{Results}

\subsection{Beetle Mortality}

Third instar $D$. coriaria are approximately three times more susceptible to the nematodes than the adults $\left(\chi^{2}=77.54\right.$, df $\left.=1, p<0.001\right)$. In the control, there was $17 \%$ adult beetle mortality and $43 \%$ mortality for the third instars (Figure 1). The main effect of nematode species was significant $\left(\chi^{2}=13.54\right.$, $\mathrm{df}=4, p=0.009)$. The dosage rate of the nematodes was not significant $\left(\chi^{2}=5.16, \mathrm{df}=2, p=0.076\right)$. 
Mortality for $D$. coriaria adults and third instars treated with $S$. feltiae and H. bacteriophora was not significantly different from the control $\left(\chi^{2}=0.03, \mathrm{df}=1, p=0.873\right.$ and $\chi^{2}=2.084, \mathrm{df}=1, p=0.149$, respectively) (Figure 1). Mortality for D. coriaria adults $(26 \%)$ and third instars $(77 \%)$ treated with $S$. carpocapsae was significantly higher than the control (Figure 1) $\left(\chi^{2}=6.24, \mathrm{df}=1, p=0.013\right.$ ) and S. feltiae $\left(\chi^{2}=7.06, \mathrm{df}=1, p=0.008\right)$, but not H. bacteriophora $\left(\chi^{2}=1.22, \mathrm{df}=1, p=0.269\right)$. Mortality for $D$. coriaria adults (34\%) and third instars (77\%) treated with $S$. riobrave was significantly higher than the control (Figure 1) $\left(\chi^{2}=6.38, \mathrm{df}=1, p=0.012\right)$ and $S$. feltiae $\left(\chi^{2}=7.09, \mathrm{df}=1, p=0.008\right)$, but not significantly different from $H$. bacteriophora $\left(\chi^{2}=1.18, \mathrm{df}=1, p=0.278\right)$ or $S$. carpocapsae $\left(\chi^{2}=0.002, \mathrm{df}=1, p=0.965\right)$. None of the interaction terms were significant.

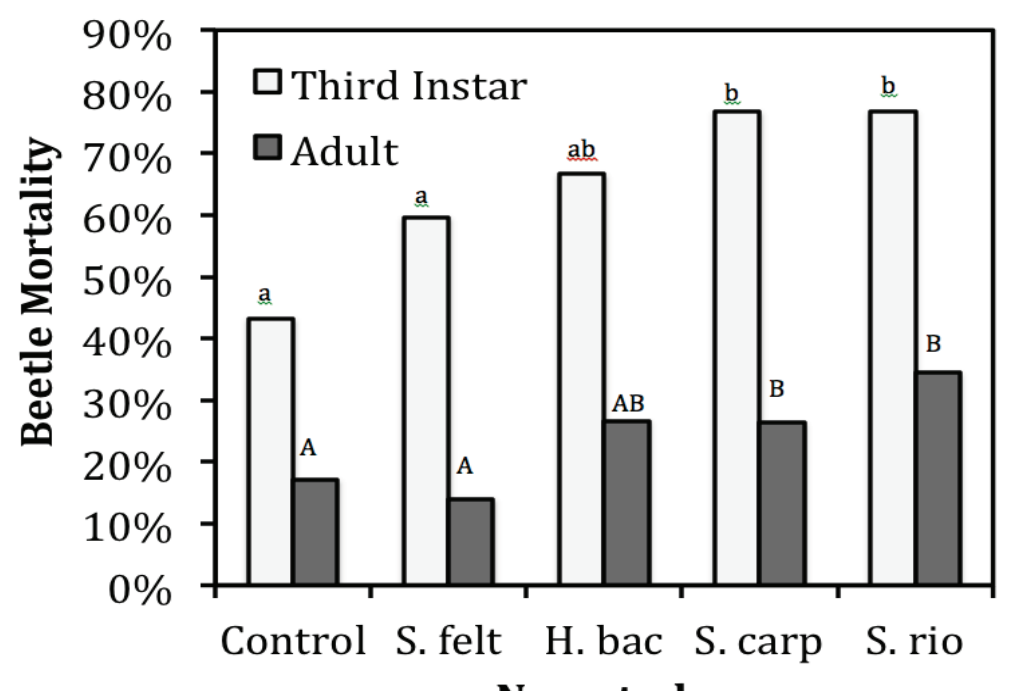

Figure 1. Percent mortality of $D$. coriaria on Day 4. Since dosage was not significant $\left(\chi^{2}=5.16, \mathrm{df}=2, p=0.076\right)$, data for dosage was combined for each nematode species. H. bac $=H$. bacteriophora, S. carp $=S$. carpocapsae, S. felt $=S$. feltiae, $\mathrm{S}$. rio $=S$. riobrave. Bars with different letters are significantly different $(p<0.05)$.

\subsection{Presence of Nematodes in Cadavers}

Not all of the dead beetles contained nematodes. Even though third instar mortality was higher in the presence of entomopathogenic nematodes than adult mortality, a similar number of nematodes were recovered from both third instars and adults $\left(\chi^{2}=237, \mathrm{df}=197, p=0.121\right)$. The main effects of nematode species and dose were significant for the number of nematodes recovered from adults and third instars $\left(\chi^{2}=246, \mathrm{df}=200, p=0.025\right.$ and $\chi^{2}=240, \mathrm{df}=198, p=0.046$, respectively $)$. The two-way interaction term for nematodes species and rate was also significant $\left(\chi^{2}=223, \mathrm{df}=191, p=0.028\right)$. There was an increasing dosage effect for $S$. feltiae and H. bacteriophora but not $S$. carpocapsae and $S$. riobrave. Nematodes were recovered from $0,18 \%$, and $40 \%$ of the adult and larval beetles that died after being treated with $S$. feltiae at the low, intermediate, and high rates, respectively, with significantly more nematodes recovered at the high rate relative to the low rate $(\mathrm{t}=2.13, \mathrm{df}=191, p=0.034)$ (Figure 2). For $H$. bacteriophora, nematodes were found in $7 \%, 8 \%$, and $47 \%$ of the dead adult and larval beetles treated at the low, intermediate, and high rates, respectively, with significantly more nematodes recovered from the high rate relative to the low and intermediate rates $(\mathrm{t}=2.13, \mathrm{df}=191, p=0.034$ and 
$\mathrm{t}=1.98, \mathrm{df}=191, p=0.049$, respectively) (Figure 2). For the $S$. carpocapsae treatment, nematodes were found in $39 \%, 41 \%$, and $36 \%$ of the dead adult and larval beetles treated at the low, intermediate, and high rates, respectively, without any significant differences between rates (Figure 2). For the $S$. riobrave treatment, nematodes were found in $42 \%, 31 \%$, and $48 \%$ of the dead adult and larval beetles treated at the low, intermediate, and high rates, respectively, without any significant differences between rates (Figure 2).

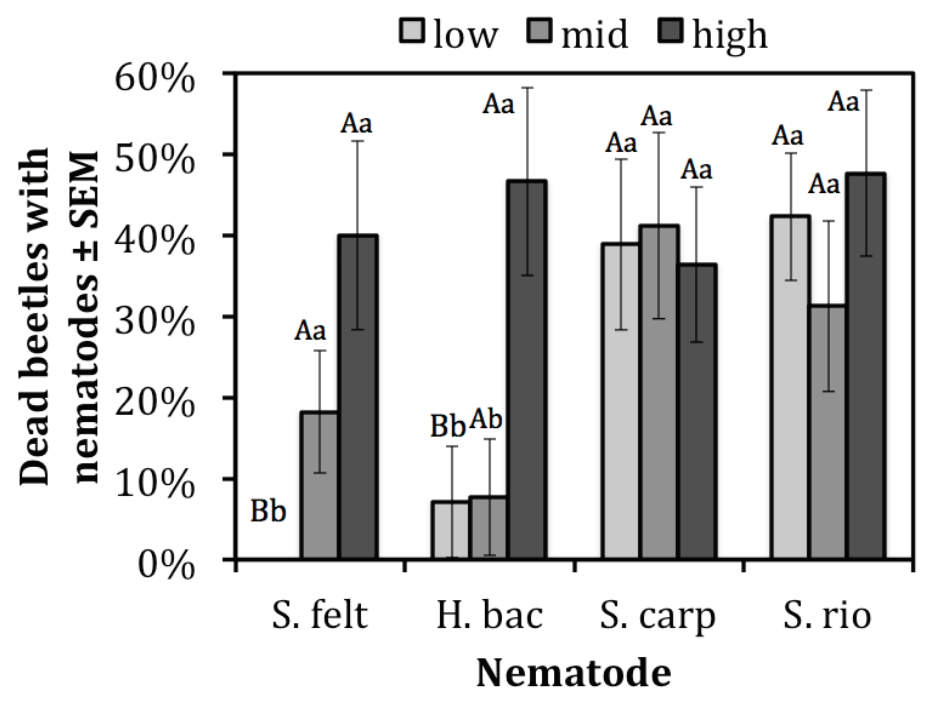

Figure 2. Percent dead D. coriaria with confirmed nematodes. H. bac $=H$. bacteriophora, $\mathrm{S}$. carp $=S$. carpocapsae, $\mathrm{S}$. felt $=S$. feltiae, $\mathrm{S}$. rio $=S$. riobrave. Within each nematode group, bars with different lowercase letters are significantly different $(p<0.05)$. For each rate across nematode species, bars with different uppercase letters are significantly different $(p<0.05)$.

\section{Discussion}

Entomopathogenic nematodes and $D$. coriaria are soil-dwelling biological control organisms that are likely to encounter each other, especially when used as part of an augmentative biological control program. A previous study tested the laboratory susceptibility of $D$. coriaria to only one nematode, $S$. feltiae, and concluded that third instar mortality is dose dependent but not adult beetle mortality [11]. The four nematode species tested in the present study were able to infect third instar and adult D. coriaria with varying success, but only $S$. carpocapsae and $S$. riobrave significantly increased mortality (Figure 1). Adult beetles were less susceptible than third instars, a pattern seen in other beetle hosts. Dalotia coriaria adults and third instars were less susceptible to $S$. feltiae than the other three species. Thus, S. feltiae appears to be a good candidate to use with $D$. coriaria in biological control programs of greenhouse pests.

In their laboratory studies, Jandricic et al. (2006) showed that adult $D$. coriaria was not susceptible to $S$. feltiae but third instar mortality was dose dependent. Mortality at the highest dose rate of $50 \mathrm{IJ} / \mathrm{cm}^{2}$ was $27 \%$, which was significantly greater than the two lower rates and control [11]. In contrast the present study did not show a dosage effect for the mortality. This inconsistency may be due to the higher doses tested. In Jandricic et al. (2006), third instars were treated with $12 \mathrm{IJ} / \mathrm{cm}^{2}, 25 \mathrm{IJ} / \mathrm{cm}^{2}$, and $50 \mathrm{IJ} / \mathrm{cm}^{2}$. Whereas, in this study, the doses were $50 \mathrm{IJ} / \mathrm{cm}^{2}, 100 \mathrm{IJ} / \mathrm{cm}^{2}$, and $200 \mathrm{IJ} / \mathrm{cm}^{2}$ and resulted in higher mortality, $74 \%, 47 \%$, and $58 \%$ for each dose respectively. 
Third instars were two to four times more likely to die than the adults. For both phytophagous and predatory beetles, adults are typically less susceptible to nematode infection, but not always [32]. Adult carrot weevil Listronotus oregonensis (LeConte) (Coleoptera: Curculionidae) is less susceptible to H. heliothidis (Khan, Brooks, and Hirschmann), S. bibionis (Steiner), and S. carpocapsae DD-136 than third instars [33]. Adult lesser mealworm Alphitobius diaperinus (Panzer) (Coleoptera: Tenebrionidae) is less susceptible to S. carpocapsae DD-136 than late instars, but not H. heliothidis or S. glaseri (Steiner) [34]. Larvae of the confused flour beetle Tribolium confusum du Val (Coleoptera: Tenebrionidae) are generally more susceptible to $S$. feltiae than the adults [35]. Multiple adult predatory beetles including Philonthus sp. (Coleoptera: Staphylinidae) were less susceptible to H. bacteriophora and S. carpocapsae than last instars [36]. It is not known why adults are generally less susceptible than larvae, but it could be due to cuticle thickness, morphological differences in body openings, or behavior [36]. Dalotia coriaria third instar mortality was $43 \%$ in our control, this was likely due to higher susceptibility to opportunistic fungi compared to adults. Whether this is a typical mortality rate for this life stage has not been determined.

Insect mortality due to entomopathogenic nematodes is correlated with behavior and morphology of both the host and nematode [22,37]. Infective juveniles that cruise are better adopted to search for sedentary hosts; whereas, ambushers are better adopted to search for mobile hosts at the soil surface. Spiracles smaller than infective juvenile body width [38] or fitted with sieve plates restrict nematodes entry [39]. In the present study, neither search strategy nor size correlates with beetle mortality. Aspects of beetle movement behavior could explain their susceptibility to nematodes.

If infective juvenile foraging strategy was a significant factor in causing $D$. coriaria mortality then there would be higher susceptibility to an ambusher than a cruiser because $D$. coriaria is highly mobile in both the larval and adult stages. Of the nematodes assayed, H. bacteriophora is a cruiser and is more effective at finding sedentary hosts [22]; S. carpocapsae is an ambusher and is more effective at finding a mobile hosts [22]. Steinernema feltiae and S. riobrave both exhibit an intermediate behavior in the search continuum $[23,40]$. The observed mortality pattern is not consistent with nematode foraging behavior. Mortality caused by the ambusher $S$. carpocapsae was not significantly greater than the mortality from the cruiser H. bacteriophora (Figure 2). Mortality from $S$. feltiae and S. riobrave, the intermediates, was lower than cruiser and higher than the ambusher, respectively, not in between them. Thus, the results do not support the hypothesis that nematode foraging behavior explains $D$. coriaria susceptibility. This pattern holds for both the mortality data and frequency of nematode establishment.

The lack of dose response in D. coriaria mortality for any of the four nematode species may have been due to the simple arena and relatively high numbers of nematodes at even the lowest dose (Figure 1). For both $S$. riobrave and $S$. carpocapsae dose did not correlate with increased colonization of the host, however, colonization by both $H$. bacteriophora and $S$. feltiae was positively correlated with dose (Figure 2). Nematode foraging strategy is one hypothesis to explain this difference if S. feltiae searched more as a "cruiser" and $S$. riobrave searched more as an "ambusher." Alternatively, differences in colonization patterns could be due to intrinsic host suitability for the four nematode species.

If $D$. coriaria mortality could be explained by the size of the infective juvenile, then $D$. coriaria would likely be more susceptible to the narrowest nematodes. The observed mortality does not correlate to infective juvenile size. The infective juvenile with the greatest width is $S$. riobrave at 28 microns [41]. With a mean body width of 26 microns, $S$. feltiae is the second largest infective juvenile [42]. Followed by $S$. carpocapsae at 25 microns and H. bacteriophora at 23 microns [42]. Dalotia coriaria showed higher susceptibility to $S$. riobrave and $S$. carpocapsae even though $H$. bacteriophora is the narrowest 
nematode. Thus, the size of natural openings did not prevent or allow certain nematode species entry into the host. The size of the beetle spiracles, anal, and oral openings is unknown.

Dalotia coriaria may be a poor host due to its relative size to nematodes. Nematodes need a host that is large enough to provide sufficient resources for reproduction. Dalotia coriaria is only 3-4 mm long and provides much less resources than G. mellonella, 12-20 mm in length. Also, from the perspective of the beetle, the infective juveniles are likely large enough - $14 \%$ to $28 \%$ the size of the beetle - to be perceived and $D$. coriaria may have developed behaviors to avoid or groom nematodes before they can enter.

\section{Conclusions}

In conclusion, D. coriaria appears to be most likely compatible with applications of $S$. feltiae and $H$. bacteriophora and less compatible with $S$. carpocapsae and $S$. riobrave. The former two nematode species did not cause significantly higher morality than the control, and established in $<20 \%$ of the beetles at or below the recommended rate for greenhouse applications. Thus, the results strongly suggest that biological control organisms $S$. feltiae and/or H. bacteriophora and D. coriaria could be applied at the same time to manage greenhouse pests such as fungus gnats and western flower thrips. This laboratory experiment presented a worse case scenario for the potential host (D. coriaria); a homogeneous habitat with limited potential refuges from a high population of foraging infective juveniles. The two-dimensional piece of vertical filter paper provided a simple environment for the infective juveniles to search and may have maximized infection. Since cruising nematodes can find hosts more effectively in a three-dimensional space than a two-dimensional space [23], potential negative interactions between D. coriaria and $S$. carpocapsae and $S$. riobrave should be confirmed in experiments that provide or approximate field conditions.

\section{Acknowledgments}

We thank Morgan Burnette and Yvonne Millar for their assistance in colony maintenance, experiment set-up, and data collection. This research was funded by the Michigan State University Ray and Bernice Hutson Memorial Entomology Endowment and the CERES trust.

\section{Author Contributions}

Joseph Tourtois lead the design and performance of the experiments, data analysis and writing of the manuscript. Matthew Grieshop provided experimental design advice, material support for the research and assisted in the analysis of data and preparation of the manuscript.

\section{Conflicts of Interest}

The authors declare no conflict of interest.

\section{References}

1. Shipp, L.; Elliott, D.; Gillespie, D.; Brodeur, J. From Chemical to Biological Control in Canadian Greenhouse Crops. In Biological Control: A Global Perspective: Case Studies from Around the World; CABI Publishing: Cambridge, MA, USA, 2007; pp. 118-127. 
2. Jensen, S.E. Insecticide resistance in the western flower thrips, Frankliniella occidentalis. Integr. Pest Manag. Rev. 2000, 5, 131-146.

3. Reitz, S.R. Biology and ecology of the western flower thrips (Thysanoptera: Thripidae): The making of a pest. Fla. Entomol. 2009, 92, 7-13.

4. Xu, X.; Borgemeister, C.; Poehling, H.-M. Interactions in the biological control of western flower thrips Frankliniella occidentalis (Pergande) and two-spotted spider mite Tetranychus urticae Koch by the predatory bug Orius insidiosus Say on beans. Biol. Control 2006, 36, 57-64.

5. Manners, A.G.; Dembowski, B.R.; Healey, M.A. Biological control of western flower thrips, Frankliniella occidentalis (Pergande) (Thysanoptera: Thripidae), in gerberas, chrysanthemums and roses. Aust. J. Entomol. 2013, 52, 246-258.

6. Gouge, D.H.; Hague, N.G.M. Glasshouse control of fungus gnats, Bradysia paupera, on fuchsias by Steinernema feltiae. Fundam. Appl. Nematol. 1995, 18, 77-80.

7. Harris, M.A.; Oetting, R.D.; Gardner, W.A. Use of entomopathogenic nematodes and a new monitoring technique for control of fungus gnats, Bradysia coprophila (Diptera: Sciaridae), in Floriculture. Biol. Control 1995, 5, 412-418.

8. Jagdale, G.B.; Casey, M.L.; Cañas, L.; Grewal, P.S. Effect of entomopathogenic nematode species, split application and potting medium on the control of the fungus gnat, Bradysia difformis (Diptera: Sciaridae), in the greenhouse at alternating cold and warm temperatures. Biol. Control 2007, 43, 23-30.

9. Carney, V.A.; Diamond, J.C.; Murphy, G.D.; Marshall, D. The potential of Atheta coriaria Kraatz (Coleoptera: Staphylinidae), as a biological control agent for use in greenhouse crops. IOBC WPRS Bull. 2002, 25, 37-40.

10. Miller, K.V.; Williams, R.N. Biology and host preference of Atheta coriaria (Coleoptera: Staphylinidae), an egg predator of Nitidulidae and Muscidae. Ann. Entomol. Soc. Am. 1983, 76, $158-161$.

11. Jandricic, S.; Scott-Dupree, C.D.; Broadbent, A.B.; Harris, C.R.; Murphy, G. Compatibility of Atheta coriaria with other biological control agents and reduced-risk insecticides used in greenhouse floriculture integrated pest management programs for fungus gnats. Can. Entomol. 2006, 138, 712-722.

12. Echegaray Wilson, E.R. Life Cycle of the Rove Beetle, Atheta coriaria (Kraatz) (Coleoptera: Staphylinidae) and Suitability as a Biological Control Agent against the Fungus Gnat, Bradysia sp. nr. Coprophila (Lintner); Kansas State University: Manhattan, KS, USA, 2012.

13. Bennison, J.; Maulden, K.; Maher, H.; Tomiczek, M. Development of a grower rearing-release system for Atheta coriaria, for low cost biological control of ground-dwelling pest life stages. IOBCwprs Bull. 2008, 32.

14. Bennison, J.; Croft, P.; Maher, H.; Maulden, K. Protected Herbs, Ornamentals and Celery: Development of an On-nursery Rearing System for Atheta coriaria for Reduced Cost Biological Control of Sciarid and Shore Flies. Available online: http://www.hdc.org.uk/project/protectedherbs-ornamentals-and-celery-development-nursery-rearing-system-atheta-coriaria-10 (accessed on 20 February 2015).

15. Kaya, H.K.; Gaugler, R. Entomopathogenic nematodes. Annu. Rev. Entomol. 1993, 38, 181-206. 
16. Ebssa, L.; Borgemeister, C.; Berndt, O.; Poehling, H.-M. Efficacy of entomopathogenic nematodes against soil-dwelling life stages of western flower thrips, Frankliniella occidentalis (Thysanoptera: Thripidae). J. Invertebr. Pathol. 2001, 78, 119-127.

17. Chyzik, R.; Glazer, I.; Klein, M. Virulence and efficacy of different entomopathogenic nematode species against western flower thrips (Frankliniella occidentalis). Phytoparasitica 1996, 24, 103-110.

18. Premachandra, W.T.S.D.; Borgemeister, C.; Berndt, O.; Ehlers, R.-U.; Poehling, H.-M. Combined releases of entomopathogenic nematodes and the predatory mite Hypoaspis aculeifer to control soil-dwelling stages of western flower thrips Frankliniella occidentalis. BioControl 2004, 48, 529-541.

19. Ebssa, L.; Borgemeister, C.; Poehling, H.-M. Effectiveness of different species/strains of entomopathogenic nematodes for control of western flower thrips (Frankliniella occidentalis) at various concentrations, host densities, and temperatures. Biol. Control 2004, 29, 145-154.

20. Lewis, E.E.; Campbell, J.; Griffin, C.; Kaya, H.; Peters, A. Behavioral ecology of entomopathogenic nematodes. Biol. Control 2006, 38, 66-79.

21. Baweja, V.; Sehgal, S.S. Potential of Heterorhabditis bacteriophora Poinar (Nematoda, Heterorhabditidae) in parasitizing Spodoptera litura Fabricius in response to malathion treatment. Acta Parasitoligica 1997, 42, 168-172.

22. Campbell, J.F.; Gaugler, R. Nictation behavior and it's ecological implications in the host search strategies of entomopathogenic nematodes (Heterorhabditidae and Steinernematidae). Behavior 1993, 126, 155-169.

23. Grewal, P.S.; Lewis, E.E.; Gaugler, R.; Campbell, J.F. Host finding behaviour as a predictor of foraging strategy in entomopathogenic nematodes. Parasitology 1994, 108, 207-215.

24. BeckerUnderwood Nemasys ${ }^{\circledR}$ Advanced Biocontrol for Fungus Gnats and Western Flower thrips in Greenhouse Growing Operations 2013. Available online: http://www.plantproducts.com/ ca/images/Nemasys\%20label.pdf (accessed on 11 March 2015).

25. Kaya, H.K.; Stock, S.P. Techniques in insect nematology. Man. Tech. Insect Pathol. 1997, C6, 281-324.

26. White, G.F. A method for obtaining infective nematode larvae from cultures. Science 1927, 66, 302-303.

27. Ramos-Rodríguez, O.; Campbell, J.F.; Ramaswamy, S.B. Pathogenicity of three species of entomopathogenic nematodes to some major stored-product insect pests. J. Stored Prod. Res. 2006, 42, 241-252.

28. SAS Institute Inc. SAS/STAT 9.2 User's Guide; SAS Institute Inc.: Cary, NC, USA, 2008.

29. Therneau, T.M. Modeling Survival Data: Extending the Cox Model; Springer Science \& Business Media: New York, NY, USA, 2000.

30. Statistical Package R. R: A Language and Environment for Statistical Computing; The R Foundation for Statisitical Computing: Vienna, Austria, 2014.

31. Kuhn, M. Contributions from Steve Weston, Wing, J.; Forester, J.; Thaler, T. Contrast: A Collection of Contrast Methods. Available online: http://rpackages.ianhowson.com/cran/contrast/ (accessed on 20 February 2015).

32. Doucet, M.; Bertolotti, M.; Giayetto, A.; Mirands, M. Host range, specificity, and virulence of Steinernema feltiae, Steinernema rarum, and Heterorhabditis bacteriophora (Steinernematidae and Heterorhabditidae) from Argentina. J. Invertebr. Pathol. 1999, 73, 237-242. 
33. Belair, G.; Boivin, G. Susceptibility of the Carrot Weevil (Coleoptera: Curculinidae) to Steinernema feltiae, S. bibionis, and Hetorhabditidis heliothidis. J. Nematol. 1985, 17, 363-366.

34. Geden, C.J.; Axtell, R.C.; Brooks, W.M. Susceptibility of the lesser mealworm, Alphitobius diaperinus (Coleoptera: Tenebrionidae) to the entomogenous nematodes Steinernema feltiae, S. glaseri (Steinernematidae) and Heterorhabditis heliothidis (Heterorhabditidae). J. Entomol. Sci. 1985, 20, 331-339.

35. Athanassiou, C.G.; Palyvos, N.E.; Kakouli-Duarte, T. Insecticidal effect of Steinernema feltiae (Filipjev) (Nematoda: Steinernematidae) against Tribolium confusum du Val (Coleoptera: Tenebrionidae) and Ephestia kuehniella (Zeller) (Lepidoptera: Pyralidae) in stored wheat. J. Stored Prod. Res. 2008, 44, 52-57.

36. Georgis, R.; Kaya, H.K.; Gaugler, R. Effect of steinernematid and heterorhabditid nematodes (RhabditidaL Steinernematidae and Heterorhabditidae) on nontarget arthropods. Environ. Entomol. 1991, 20, 815-822.

37. Lewis, E.E.; Ricci, M.; Gaugler, R. Host recognition behaviour predicts host suitability in the entomopathogenic nematode Steinernema carpocapsae (Rhabditida: Steinernematidae). Parasitology 1996, 113, 573-579.

38. Henneberry, T.J.; Lindegren, J.E.; Jech, L.F.; Burke, R.A. Pink bollworm (Lepidoptera: Gelechiidae), cabbage looper, and beet army worm (Lepidoptera: Noctuidae) pupal susceptibility to steinernematid nematodes (Rhabditida: Steinernematidae). J. Econ. Entomol. 1995, 88, 835-839.

39. Koppenhöfer, A.M.; Grewal, P.S.; Fuzy, E.M. Differences in penetration routes and establishment rates of four entomopathogenic nematode species into four white grub species. J. Invertebr. Pathol. 2007, 94, 184-195.

40. Millar, L.C.; Barbercheck, M.E. Interaction between endemic and introduced entomopathogenic nematodes in conventional-till and no-till corn. Biol. Control 2001, 22, 235-245.

41. Cabanillas, H.E.; Poinar, G.O.; Raulston, J.R. Steinernema riobravis n. sp. (Rhabditida: Steinernematidae) from Texas. Fundam. Appl. Nematol. 1994, 17, 123-131.

42. Poinar, G.O. Taxonomy and Biology of Steinernematidae and Heterorhabditidae. In Entomopathogenic Nematodes in Biological Control; CRC Press, Inc.: Boca Raton, FL, USA, 1990; pp. 23-62.

(C) 2015 by the authors; licensee MDPI, Basel, Switzerland. This article is an open access article distributed under the terms and conditions of the Creative Commons Attribution license (http://creativecommons.org/licenses/by/4.0/). 